\title{
PERSEPSI MAHASISWA STIKES HARAPAN IBU JAMBI TERHADAP PEMBELAJARAN DARING VIA ZOOM PADA MASA PANDEMI COVID-19
}

\author{
Deny Sutrisno $^{1}$, Lia Anggresani ${ }^{2}$, Muammar Khadafi ${ }^{3}$ \\ 1,2,3Farmasi, Sekolah Tinggi Ilmu Kesehatan Harapan Ibu Jambi \\ Jl. Tarmizi Kadir No. 71, Pakuan Baru, Jambi Selatan, Kota Jambi \\ ${ }^{1}$ Email: denysutrisno@gmail.com \\ ${ }^{2}$ Email: anggresani@yahoo.com \\ ${ }^{3}$ Email: amarkhadafi242@gmail.com
}

\begin{abstract}
ABSTRAK
Tujuan penelitian ini adalah untuk mengetahui persepsi mahasiswa Sekolah Tinggi Ilmu Kesehatan Ibu Jambi terhadap pembelajaran daring via Zoom pada masa pandemi Covid-19. Metode. Penelitian ini menggunakan metode deskritif. Pengumpulan sampel dilakukan dengan menggunakan teknik non probability sampling dengan pendekatan aksiden sampling. Hasil penelitian ini menunjukkan bahwa ekspektansi mahasiswa terhadap penggunaan zoom adalah agar dapat mempermudah dalam pembelajaran daring, digunakan dalam pembelajaran teori dan juga untuk diskusi dengan teman.
\end{abstract}

Kata Kunci: Presepsi mahasiswa, aplikasi zoom, covid-19

\begin{abstract}
The purpose of this study was to determine the perceptions of Sekolah Tinggi Ilmu Kesehatan Ibu Jambistudents towards online learning via Zoom during the Covid-19 pandemic. Method. This research used descriptive method. The sample was collected using a non-probability sampling technique with an accidental sampling approach. The results of this study indicated that students' expectations of the use of zoom were to make online learning easier, used in theory learning and also for discussion with friends.
\end{abstract}

Keyword: Student perception, zoom app, covid-19

\section{PENDAHULUAN}

Salah satu aplikasi yang digunakan dosen STIKES Harapan Ibu Jambi untuk melakukan kuliah daring adalah Zoom. Pembelajaran daring sebenarnya memerlukan peran aktif orang tua (Elihami, 2021), namun mahasiswa sudah memiliki karakter kemandirian dalam belajar. Penelitian di STIKES Surabaya (Ferdiana, 2020) menunjukkan zoom merupakan aplikasi yang disukai oleh mahasiswa untuk pembelajaran daring setelah Whatsapp grup. Penelitian tersebut menunjukkan persepsi mahasiswa terhadap media yang disukai dan tidak disukai dengan hasil 3 media teratas yang paling disukai adalah WhatsApp Group sebesar 41.7\%, Zoom 28.2\% dan Google classroom \& meeting sebesar 8.7\%. Walaupun begitu di tempat lain menunjukkan bahwa Penggunaan Zoom direspon negatif oleh sebagian besar mahasiswa (Mulyana, Rainanto, Astrini, \& Puspitasari, 2020). 
Bahkan penelitian yang menunjukkan ahasiswa secara kesuluruhan memilih kuliah tatap muka dibandingkan dengan kuliah online (Anhusadar, 2020).

Selain kelebihan-kelebihan zoom juga memiliki kekurangan. Diantaranya zoom terkadang terputus jaringannya disaat pembelajaran (Cuaca Dharma, Asmarani, \& Dewi, 2017). Untuk mengatasi kekurangan Zoom yang mungkin ada maka diperlukan umpan balik dari siswa (Saha, Roy, \& Ray, 2021). Karena itu diperlukan studi untuk mengetahui persepsi mahasiswa mahasiswa Sekolah Tinggi Ilmu Kesehatan Ibu Jambi terhadap pembelajaran daring via Zoom.

Penggunaan zoom di Sekolah Tinggi Ilmu Kesehatan Ibu Jambi perlu lihat apakah efektif seperti penelitian di tempat lain (Hermansah, Lubis, \& Nuzulia, 2020; Ismawati \& Prasetyo, 2020). Keefektifitasan pembelajran melalui zoom perlu diperhatikan agar mahasiswa memahami pelajaran saat perkuliahan berlangsung (Monica \& Fitriawati, 2020). Peningkatan peran dan keaktifan mahasiswa dalam penggunaan berbagai media dan teknologi demi suksesnya perkuliahan daring sangatlah dipengaruhi oleh persepsi. Dari hal di atas maka perlu dilakukan penelitian untuk mengetahui persepsi mahasiswa Sekolah Tinggi Ilmu Kesehatan Ibu Jambi terhadap pembelajaran daring via Zoom pada masa pandemi Covid-19.

\section{METODE PENELITIAN}

Penelitian ini menggunakan metode deskritif. Pengumpulan sampel dilakukan dengan menggunakan teknik non probability sampling dengan pendekatan aksiden sampling. Tahapan penelitian dapat dilihat pada gambar 1 berikut ini:

\begin{tabular}{|c|c|} 
Pembuatan \\
Intrumen \\
penelitan
\end{tabular}$\quad \begin{gathered}\text { Validasi } \\
\text { Instrumen } \\
\text { Penelitian } \\
\text { Data Presepsi } \\
\text { Mahasiswa }\end{gathered} \quad \begin{gathered}\text { Pengolahan } \\
\text { Data }\end{gathered}$

\section{Pembuatan Instrumen Penelitian}

Gambar 1. Tahapan Penelitian

Instrumen penelitian berupa kuesioner yang menggunakan skala Likert dengan 5 poin yakni Sangat Setuju (SS), Setuju (S), Netral (N), Tidak Setuju (TS), dan Sangat Tidak Setuju (STS). Kisi-kisi (Tabel 1) instrument penelitian ini memiliki 2 variabel dan 6 sub variable (Khasanah \& Syarifah, 2021) yang meliputi:

1. Ekspektansi kinerja pada penggunaan aplikasi zoom

2. Ekspektansi usaha pada penggunaan aplikasi zoom 
3. Faktor sosial pada penggunaan aplikasi zoom

4. Kondisi yang memfasilitasi pada penggunaan aplikasi zoom

5. Minat pemanfaatan pada penggunaan aplikasi zoom

6. Perilaku penggunaan pada penggunaan aplikasi zoom

Tabel 1. Kisi-kisi Kuisioner Presepsi mahasiswa

\begin{tabular}{|c|c|c|}
\hline Variabel & Sub Variabel & Item Pernyataan \\
\hline \multirow{13}{*}{$\begin{array}{c}\text { Ekspektansi } \\
\text { penggunaan } \\
\text { Zoom }\end{array}$} & \multirow{9}{*}{$\begin{array}{l}\text { Ekspektansi } \\
\text { Kinerja pada } \\
\text { penggunaan } \\
\text { aplikasi } \\
\text { Zoom }\end{array}$} & $\begin{array}{l}\text { Saya merasa bahwa aplikasi zoom dapat membantu aktivitas } \\
\text { pembelajaran daring menjadi lebih mudah. }\end{array}$ \\
\hline & & $\begin{array}{l}\text { Saya merasa bahwa aplikasi zoom relevan digunakan untuk } \\
\text { aktivitas pembelajaran daring. }\end{array}$ \\
\hline & & $\begin{array}{l}\text { Saya merasa bahwa aplikasi zoom memberikan manfaat dalam } \\
\text { aktivitas pembelajaran daring selama pandemic covid-19 }\end{array}$ \\
\hline & & $\begin{array}{l}\text { Saya merasa bahwa aplikasi zoom memberikan pengalaman baru } \\
\text { dalam aktivitas pembelajaran daring selama pandemi covid-19 }\end{array}$ \\
\hline & & $\begin{array}{l}\text { Dengan menggunakan aplikasi zoom dapat lebih efisien untuk } \\
\text { menjalin komunikasi antara dosen dan mahasiswa. }\end{array}$ \\
\hline & & $\begin{array}{l}\text { Dengan menggunakan aplikasi zoom dapat meningkatkan peluang } \\
\text { keberhasilan pembelajaran yang telah direncanakan. }\end{array}$ \\
\hline & & $\begin{array}{l}\text { Saya merasa bahwa kemampuan teknologi informasi menjadi } \\
\text { bekal penting untuk dapat menggunakan aplikasi zoom }\end{array}$ \\
\hline & & $\begin{array}{l}\text { Saya merasa bahwa aplikasi zoom dapat meningkatkan } \\
\text { produktivitas selama masa pandemi covid-19 }\end{array}$ \\
\hline & & $\begin{array}{l}\text { Saya merasa bahwa aplikasi zoom memfasilitasi saya untuk lebih } \\
\text { kreatif dalam pembelajaran selama pandemi covid-19 }\end{array}$ \\
\hline & \multirow{4}{*}{$\begin{array}{l}\text { Ekspektansi } \\
\text { Usaha pada } \\
\text { penggunaan } \\
\text { aplikasi } \\
\text { Zoom }\end{array}$} & Saya dapat dengan mudah mengoperasikan aplikasi zoom \\
\hline & & $\begin{array}{l}\text { Saya dapat dengan mudah mengoperasikan beberapa fitur aplikasi } \\
\text { zoom }\end{array}$ \\
\hline & & $\begin{array}{l}\text { Dengan menggunakan aplikasi zoom dapat membuat kegiatan } \\
\text { pembelajaran semakin rumit }\end{array}$ \\
\hline & & $\begin{array}{l}\text { Dengan menggunakan aplikasi zoom memungkinkan saya untuk } \\
\text { menyelesaikan beberapa mata kuliah dengan lebih efektif }\end{array}$ \\
\hline \multirow{9}{*}{$\begin{array}{l}\text { Faktor } \\
\text { Penggunaan } \\
\text { Zoom }\end{array}$} & \multirow{3}{*}{$\begin{array}{l}\text { Faktor Sosial } \\
\text { pada } \\
\text { penggunaan } \\
\text { aplikasi } \\
\text { Zoom }\end{array}$} & Saya menggunakan aplikasi zoom karena pengaruh dari orang lain \\
\hline & & $\begin{array}{l}\text { Saya nyaman menggunakan aplikasi zoom. Karena ada beberapa } \\
\text { orang yang membantu saya dalam menggunakan aplikasi zoom. }\end{array}$ \\
\hline & & $\begin{array}{l}\text { Saya menggunakan aplikasi zoom karena proses pembelajaran } \\
\text { mengharapkan saya untuk menggunakan aplikasi zoom. }\end{array}$ \\
\hline & \multirow{5}{*}{$\begin{array}{l}\text { Kondisi yang } \\
\text { Memfasilitasi } \\
\text { pada } \\
\text { penggunaan } \\
\text { aplikasi } \\
\text { Zoom }\end{array}$} & $\begin{array}{l}\text { Saya nyaman menggunakan aplikasi zoom karena dapat } \\
\text { digunakan dengan mudah }\end{array}$ \\
\hline & & $\begin{array}{l}\text { Saya nyaman menggunakan aplikasi zoom karena saya memiliki } \\
\text { kemampuan untuk menggunakannya. }\end{array}$ \\
\hline & & $\begin{array}{l}\text { Saya menggunakan aplikasi zoom karena fungsi yang disediakan } \\
\text { aplikasi zoom sesuai dengan kebutuhan aktivitas pembelajaran } \\
\text { daring. }\end{array}$ \\
\hline & & $\begin{array}{l}\text { Saya merasa bahwa aplikasi zoom merupakan salah satu e- } \\
\text { learning yang dapat mendukung aktivitas pembelajaran secara } \\
\text { daring. }\end{array}$ \\
\hline & & $\begin{array}{l}\text { Saya merasa bahwa penggunaan aplikasi zoom yang disarankan } \\
\text { oleh dosen saya penting untuk menunjang kemampuan IT saya. }\end{array}$ \\
\hline & $\begin{array}{c}\text { Minat } \\
\text { Pemanfaatan } \\
\end{array}$ & $\begin{array}{l}\text { Saya ingin terus menerus menggunakan aplikasi zoom untuk } \\
\text { aktivitas pembelajaran secara daring. }\end{array}$ \\
\hline
\end{tabular}




\begin{tabular}{|c|c|l|l|}
\hline Variabel & Sub Variabel & \multicolumn{4}{|c|}{ Item Pernyataan } \\
\hline & aplikasi & Saya menggunakan aplikasi zoom karena para teman sekelas \\
& Zoom & menyetujui untuk menggunakan aplikasi zoom. & \\
\cline { 2 - 5 } & $\begin{array}{c}\text { Perilaku } \\
\text { Pengguna } \\
\text { aplikasi } \\
\text { Zoom }\end{array}$ & $\begin{array}{l}\text { Saya dapat menggunakan aplikasi zoom dengan mudah dalam } \\
\text { melakukan aktivitas pembelajaran daring. }\end{array}$ \\
\cline { 3 - 5 } & $\begin{array}{l}\text { Saya merasa bahwa aplikasi zoom membingungkan Ketika } \\
\text { pertama kali digunakan sehingga saya malas untuk } \\
\text { menggunannya lagi. }\end{array}$ \\
\hline
\end{tabular}

\section{Validasi Instrumen Penelitian}

Dalam penelitian ini, untuk mengukur validitas instrumen digunakan validitas isi. Validasi isi dilakukan oleh empat orang validator yang menilai isi dari instrument penelitan. Validator memberikan masukan saran dan menentukan kelayakan dari instrument untuk digunakan.

\section{Pengambilan Data Presepsi Mahasiswa}

Pengumpulan data dilakukan dengan menyebarkan angket kuesioner secara daring menggunakan Google Form yang dikirimkan kepada mahasiswa melalui media sosial. Para mahasiswa diminta untuk mengisi kuesioner yang telah dibagikan. Populasi penelitian ini adalah seluruh mahasiswa aktif STIKES Harapan Ibu Jambi yang berjumlah 775 mahasiswa. Berdasarkan rumus penentuan sampel minimal Isaac dan Michael toleransi kesalahan 5\% sampel minimal yang diperlukan adalah 245. Sampel yang didapat pada penelitian ini adalah 265 orang dan telah memenuhi ketentuan minimal sampel yang dibutuhkan.

\section{Pengolahan Data}

Analisis data dari hasil penelitian ini menggunakan model interaktif kualitatif yang terdiri dari tiga tahapan, yakni reduksi data, display data, serta penarikan dan verifikasi kesimpulan. Reduksi data dengan cara merekap jumlah jawaban setiap item pertanyaan. Display data dilakukan dengan menampilkan data pada table. Tabel hasil rekapan jawaban akan berbentuk presentase setiap pilihan jawaban terhadap jumlah sampel.

Data ditafsirkan dengan melihat modus di setiap komponen jawaban per item. Komponen tersebut meliputi ekspektansi kinerja pada penggunaan aplikasi zoom, ekspektansi usaha pada penggunaan aplikasi zoom, faktor sosial pada penggunaan aplikasi zoom, kondisi yang memfasilitasi pada penggunaan aplikasi zoom, minat pemanfaatan pada penggunaan aplikasi zoom dan perilaku penggunaan pada penggunaan aplikasi zoom.

Hasil penelitian dilihat dengan melihat modus di setiap komponen jawaban per item perhatian. Kemudian didapat presepsi mahasiswa dalam kegiatan Daring Via Zoom Pada Masa Pandemi Covid-19 dalam hal ekspektansi penggunaan zoom dan faktor penggunaan zoom. 


\section{HASIL DAN PEMBAHASAN}

Berikut hasil angket yang diperoleh dari pengambilan data angket. Gambar 1 menunjukkan distribusi rata-rata biaya kuota internet per bulan. Setiap bulan mahasiswa mengeluarkan biaya antara Rp 100.000 sampai dengan Rp 200.000 untuk kebutuhan kuota internet. Biaya ini dirasa cukup terjangkau bagi mahasiswa dan hal ini menunjukkan bahwa kuota internet sudah menjadi suatu kebutuhan pokok mahasiswa karena perlu pengalokasian dana khusus untuk mendapatkannya.

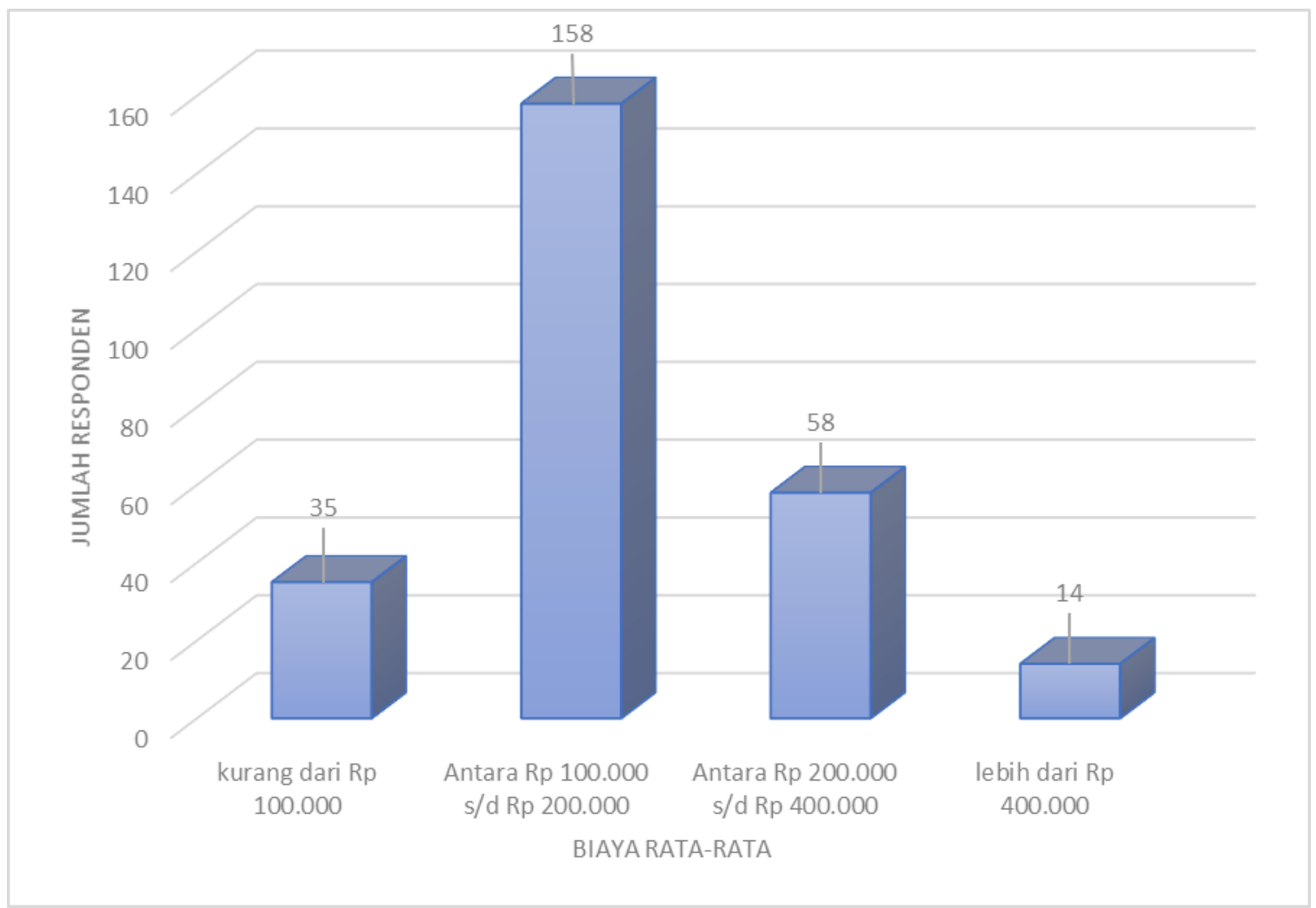

Gambar 1. Distribusi rata-rata biaya kuota internet per bulan

Gambar 2 menunjukkan ekspektasi mahasiswa terhadap kinerja penggunaan zoom. Dari tren gambar hasil kuisioner menunjukkan mahasiswa lebih banyak sangat setuju untuk berharap zoom dapat menjaga komunikasi antara dosen dan mahasiswa, antar mahasiswa dan untuk melakukan diskusi dengan sesama teman. Juga mahasiswa berharap aplikasi ini dapat mempermudah mahasiswa dalam melaksanakan pembelajaran online. Pada penelitian lain menunjukkan hal berbeda bahwa mahasiswa tidak terlalu menyukai perkuliahan dengan zoom (Ningsih, 2020), mereka lebih menyukai google classroom. 


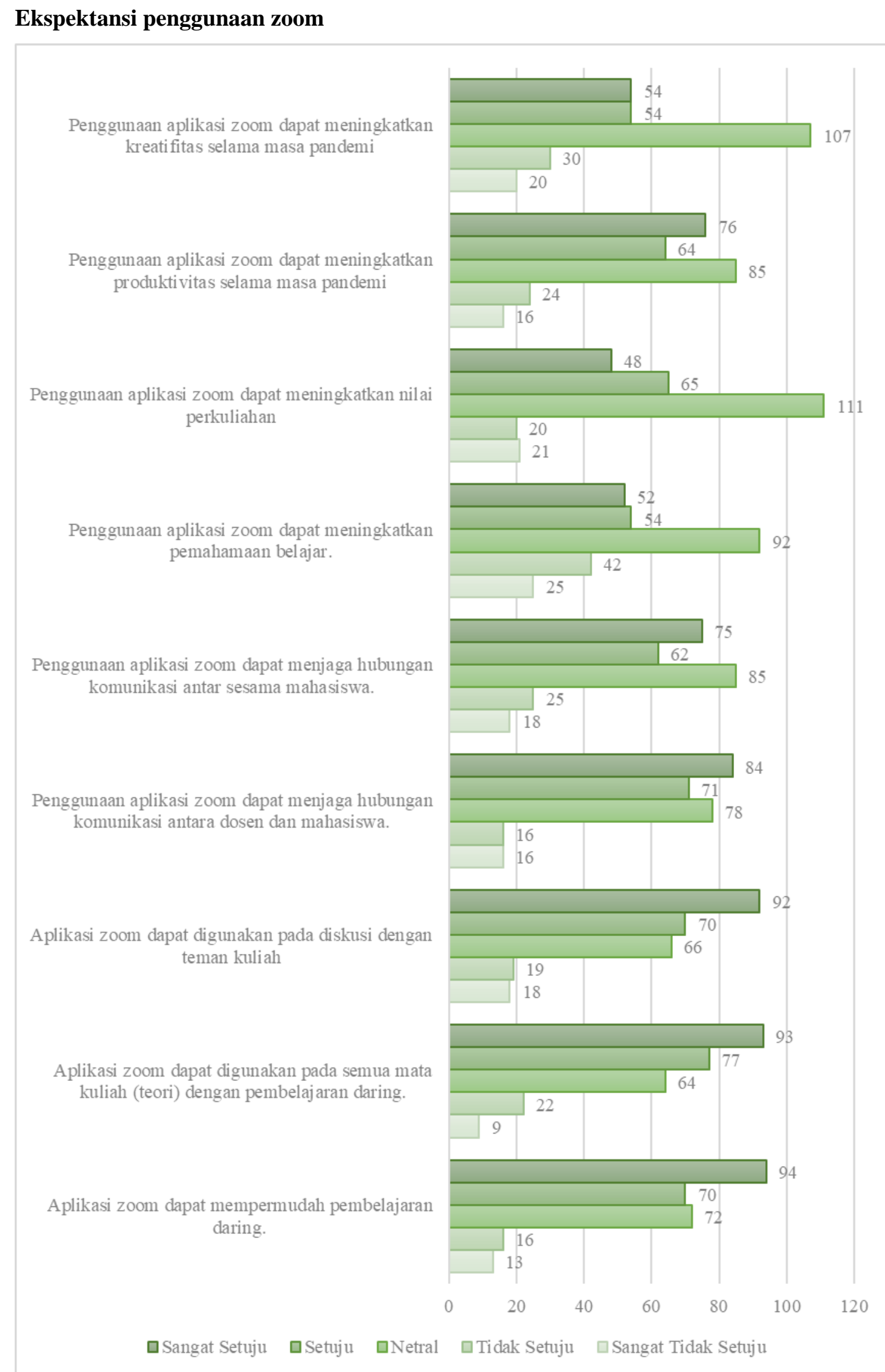

Gambar 2. Ekspektansi Kinerja pada penggunaan aplikasi Zoom 


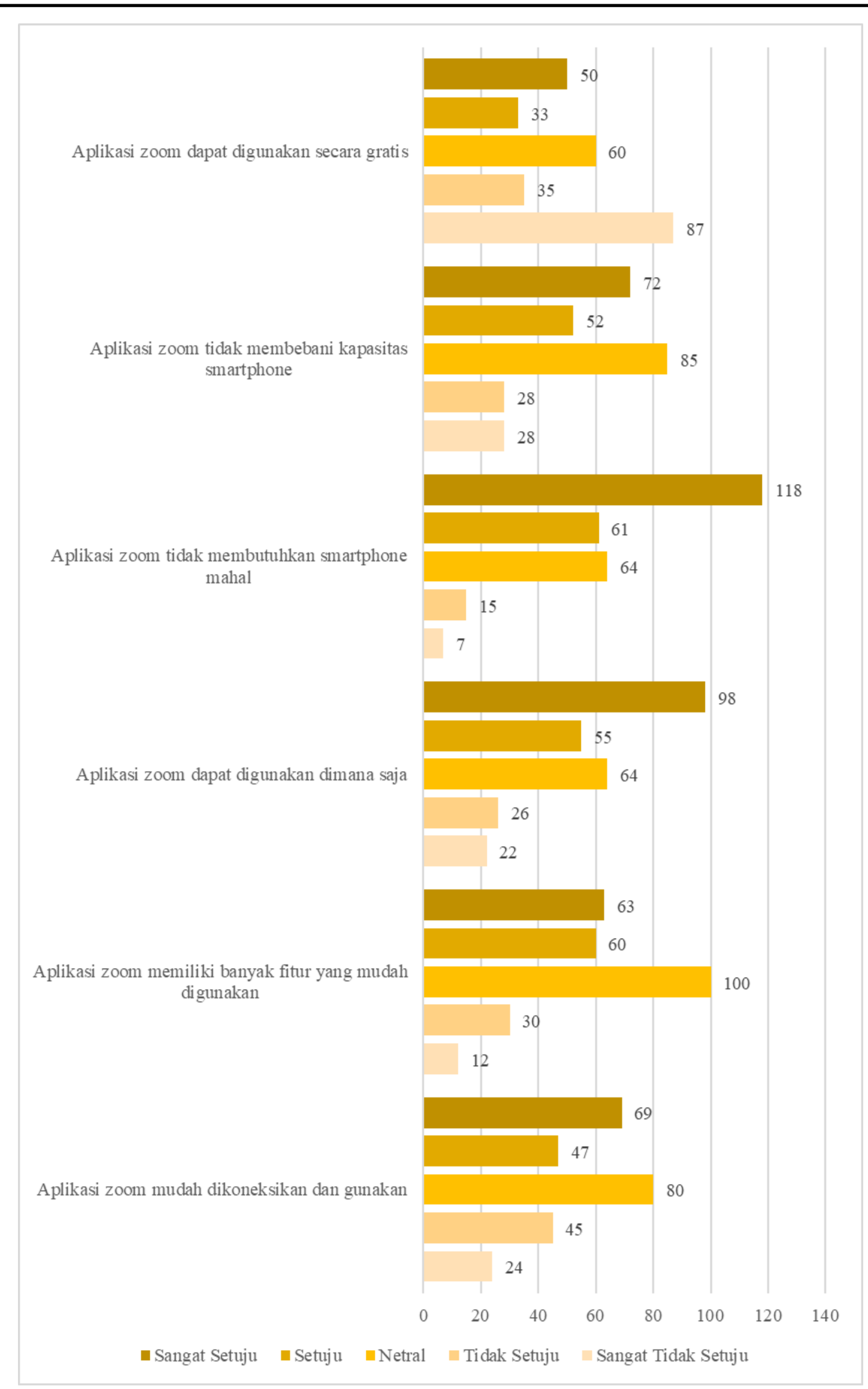

Gambar 3. Ekspektansi Usaha pada penggunaan aplikasi Zoom 


\section{Faktor penggunaan zoom}

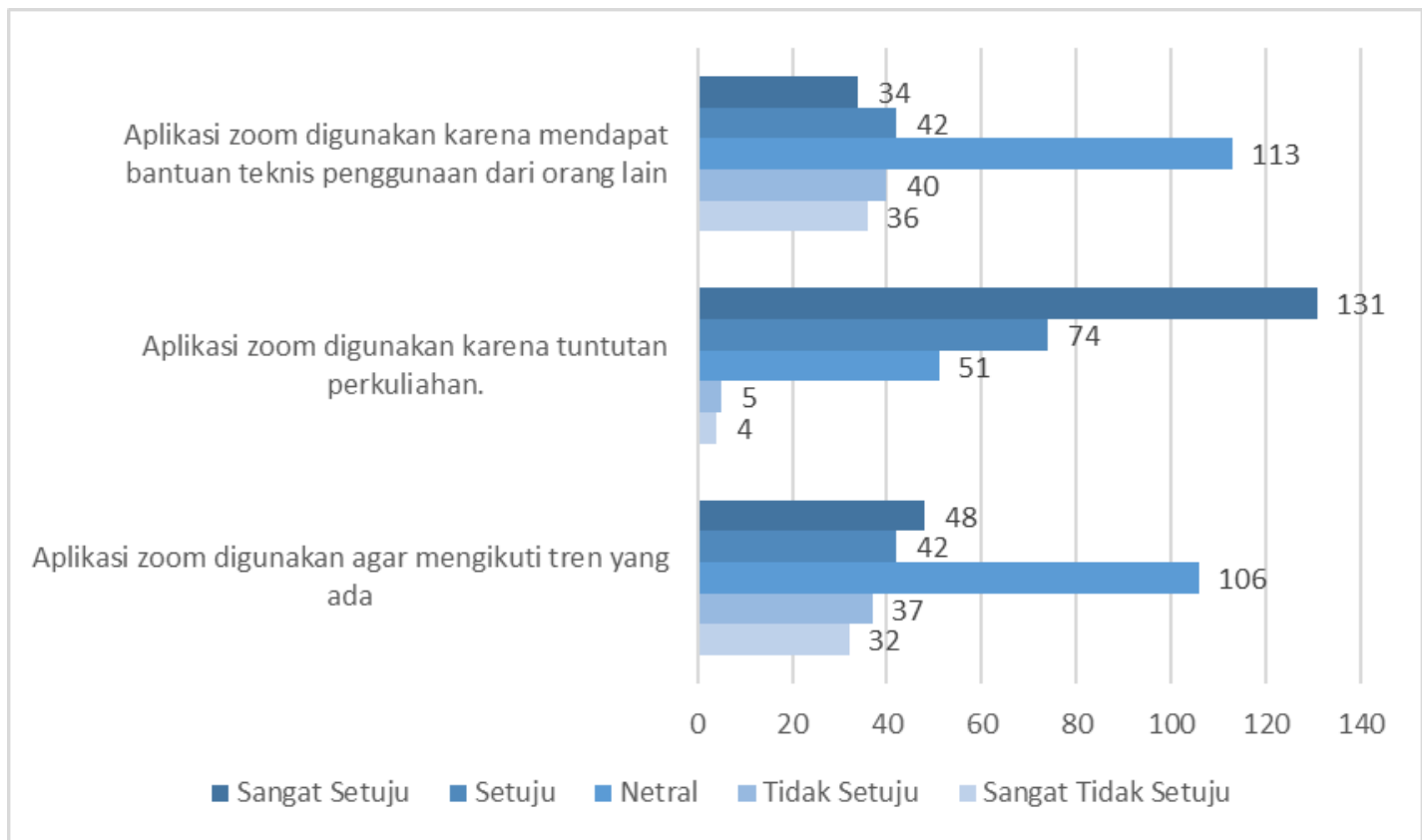

\section{Gambar 4. Faktor Sosial pada penggunaan aplikasi Zoom}

Aplikasi zoom dapat digunakan jika ada kombinasi media e-learning lain seperti Learning

Management System (LMS), video youtube, google form atau lainnya.

Aplikasi zoom merupakan salah satu e-learning yang dapat mendukung aktivitas pembelajaran secara daring.

Aplikasi zoom memiliki fitur rekam (record) yang membantu pengguna
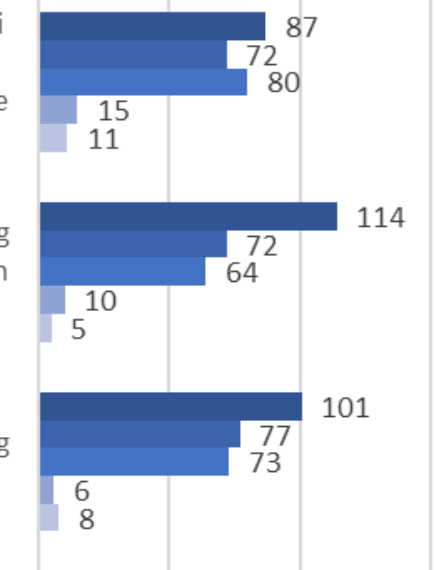

Penggunaan aplikasi zoom memerlukan sinyal seluler yang memadai

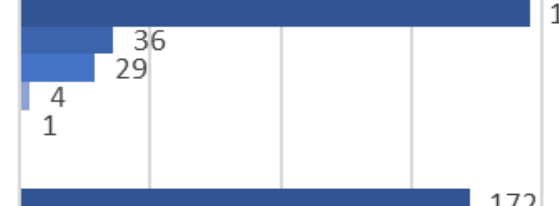

Penggunaan aplikasi zoom memerlukan kuota data intenet yang mencukupi

Aplikasi zoom digunakan jika kita memiliki perangkat yang mendukungnya seperti laptop atau smartphone

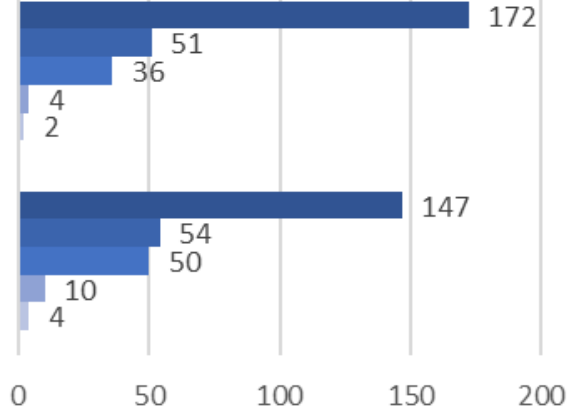

Gambar 5. Faktor Kondisi yang Memfasilitasi pada penggunaan aplikasi Zoom 


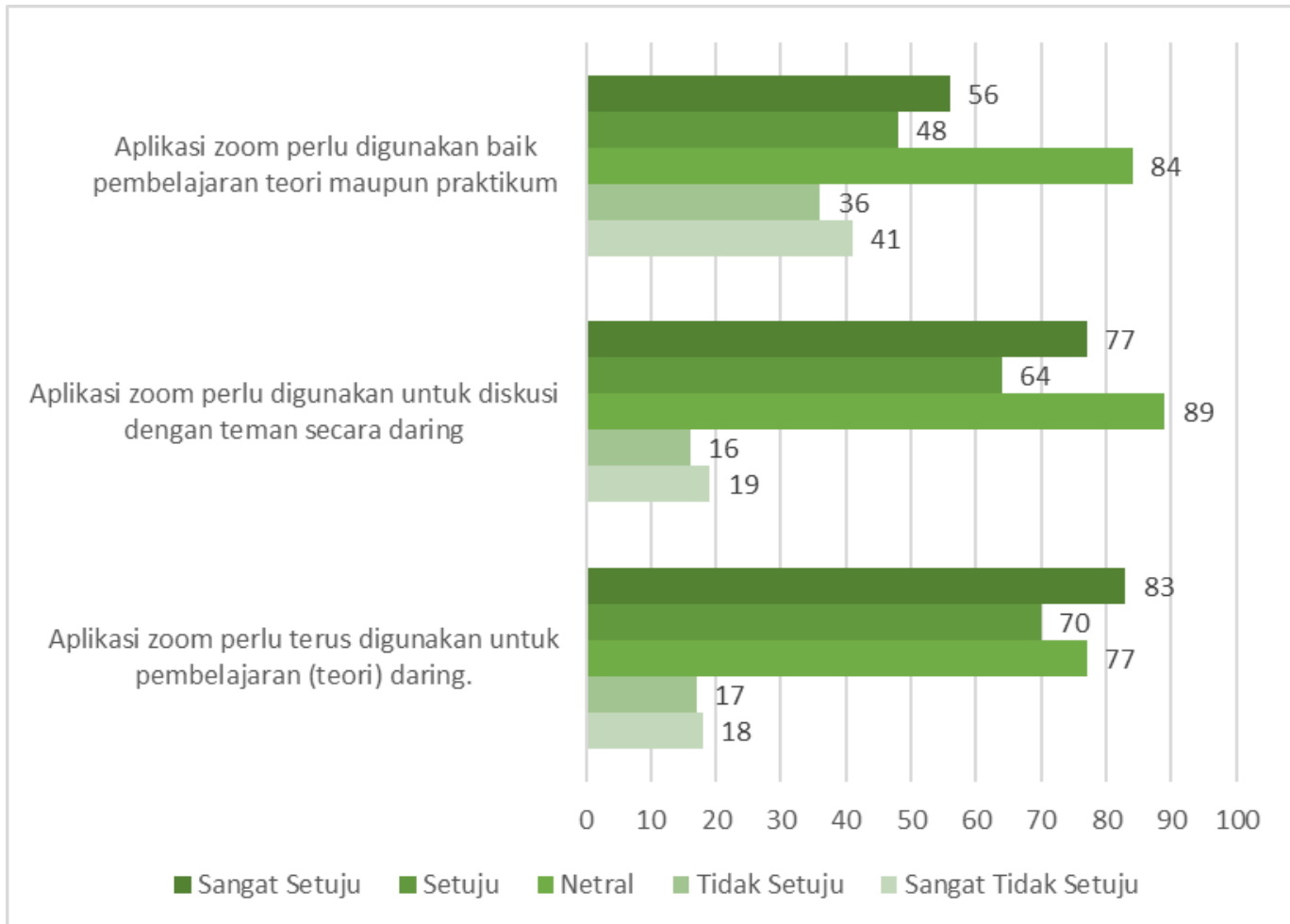

Gambar 6. Faktor Minat Pemanfaatan pada penggunaan aplikasi Zoom

Belajar menggunakan aplikasi zoom membuat saya berkesempatan melakukan aktivitas lain saat belajar

Belajar menggunakan aplikasi zoom membuat saya lebih aktif mencatat/merekam materi

Belajar menggunakan aplikasi zoom membuat penguasaan materi saya lebih baik

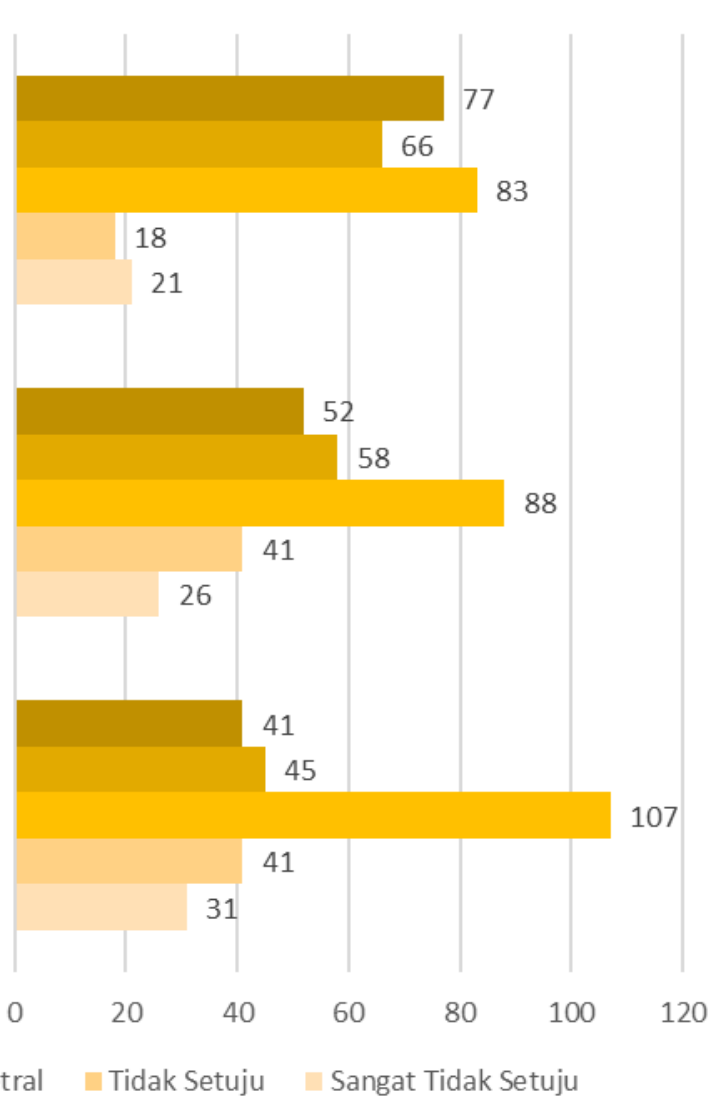

\angat Setuju $\square$ Setuju $\square$ Netral $\square$ Tidak Setuju $\square$ Sangat Tidak Setuju

Gambar 7. Faktor Perilaku Pengguna aplikasi Zoom 
Gambar 3 menunjukkan ekspektasi usaha dalam penggunaan zoom. Kebayakan mahasiswa sangat setuju bahwa aplikasi ini tidak membutuhkan smarphone mahal dan dapat dilakukan dimana saja. Bagi mahasiswa aplikasi untuk pembelajaran online sangat mudah digunakan (Rusdiantho \& Elon, 2021), hasil penelitian ini menjelaskan beberapa alasannya yaitu peralatan dan tempat yang diperlukan dapat terjangkau oleh mahasiswa.

Mahasiswa memiliki faktor mengapa mereka menggunakan zoom. Faktor sosial penggunaan zoom yang ditunjukkan pada gambar 4 adalah karena tuntutan perkuliahan. Hal ini sejalan dengan penelitian yang nunjukkan bahwa umumnya mahasiswa merasa terhambat dan tidak setuju dengan pembelajaran daring (Cahyawati \& Gunarto, 2020). Namun mahasiswa harus tetap melakukan pembelajaran daring terutama dengan zoom karena tuntutan perkuliahan.

Hambatan-hambatan yang dialami mahasiswa dapat dilihat pada gambar 5 . Hambatan tersebut adalah aplikasi ini memerlukan sinyal yang memadai, kuota internet yang cukup dan harus memiliki perangkat yang mendukung seperti laptop. Hal ini karena Sebagian mahasiswa berdomisili di daerah pedesaan. Penelitian lain juga menunjukkan bahwa untuk daeral rural penggunakan teknologi pembelajaran tidak sebaik di perkotaan (Maulana \& Hamidi, 2020). Ketersediaan sinyal di daerah pedesaan tidak sebaik di perkotaan.

Walaupun dengan kendala yang ada mahasiswa tetap memiliki minat dalam pemanfaatan aplikasi zoom. Seperti terlihat pada gambar 6, data menunjukkan mahasiswa merasa perlunya menggunakan aplikasi zoom pada diskusi dan perkuliahan teori. Namun untuk melakukan diskusi dan perkulihan teori diperlukan aspek kapabilitas dosen (Saragih, Sebayang, Sinaga, \& Ridlo, 2020). Dosen dengan kapabilitas yang baik terhadap aplikasi zoom akan meningkatkan minat mahasiswa dalam penggunaan zoom pada perkuliahan teori maupun diskusi. Dosen perlu memberikan motivasi kepada mehasiswa agar dapat menerima materi saat pembelajaran via zoom berlangsung. Kemampuan ini akan membuat mehasiswa selalu fokus terhadap berbagai penyampaian yang diberikan dosen kepadanya sehingga materi dapat tersampaikan dengan baik.

Pada sisi lain penggunaan aplikasi zoom membuat mahasiswa mudah terganggu untuk melakukan aktifitas lain. Seperti ditunjukkan pada gambar 7 bahwa mahasiswa menjadi berkesempatan melakukan pekerjaan yang lain. Ini menunjukkan ketidakfokusan mahasiswa dalam belajar. Padahal dalam penerimaan materi saat pembelajaran teori diperlukan focus dalam melakukan pembelajaran. 


\section{SIMPULAN}

Ekspektansi mahasiswa terhadap penggunaan zoom adalah agar dapat mempermudah dalam pembelajaran daring, digunakan dalam pembelajaran teori dan juga untuk diskusi dengan teman. Penggunaan aplikasi zoom juga dapat dilakukan dimana saja dan tidak membutuhkan handphone yang mahal. Kondisi yang harus dipenuhi oleh mahasiswa adalah aplikasi ini membutuhkan sinyal seluler yang memadai dan kuota internet yang mencukupi.

\section{SARAN}

Untuk penelitian selanjutnya disarankan untuk menelusuri lebih lanjut bagaimana penggunaan zoom oleh mahasiswa diluar perkuliahan seperti untuk melakukan diskusi dan lainnya. Selain itu juga perlu dilakukan penelitian yang lebih dalam mengenai kesulitan yang dialami oleh mahasiswa dalam menggunakan aplikasi zoom selain membutuhkan sinyal yang memadai dan kuota internet yang mencukupi.

\section{DAFTAR PUSTAKA}

Anhusadar, L. (2020). Persepsi Mahasiswa PIAUD terhadap Kuliah Online di Masa Pandemi Covid 19. KINDERGARTEN: Journal of Islamic Early Childhood Education, 3(1), 44. https://doi.org/10.24014/kjiece.v3i1.9609

Cahyawati, D., \& Gunarto, M. (2020). Persepsi mahasiswa terhadap pembelajaran daring pada masa pandemi Covid-19. Jurnal Inovasi Teknologi Pendidikan, 7(2), 150-161. https://doi.org/10.21831/JITP.V7I2.33296

Cuaca Dharma, H. R., Asmarani, D., \& Dewi, U. P. (2017). Basic Japanese Grammar and Conversation e-learning through Skype and Zoom Online Application. Procedia Computer Science, 116, 267-273. https://doi.org/10.1016/j.procs.2017.10.055

Elihami, E. (2021). E-Learning In Islamic Education And Pancasila On During Covid-19 Pandemic. Academy of Education Journal, 12(2), 303-310. https://doi.org/10.47200/AOEJ.V12I2.746

Ferdiana, S. (2020). Persepsi Mahasiswa tentang Penggunaan Media Daring pada Program Studi S1 Ilmu Gizi Sekolah Tinggi Ilmu Kesehatan Surabaya selama Masa Pandemi Corona Virus Disease (COVID-19). Indonesian Journal of Science Learning, 1(1), $5-12$.

Haryadi, R., \& Selviani, F. (2021). PROBLEMATIKA PEMBELAJARAN DARING DI MASA PANDEMI COVID-19. Academy of Education Journal, 12(2), 254-261. https://doi.org/10.47200/aoej.v12i2.447

Hermansah, B., Lubis, P. H. M., \& Nuzulia, D. (2020). Efektivitas Pengenalan Aplikasi Zoom Meeting Di Kecamatan Belitang Iii Oleh Mahasiswa Kkl / Kkn Universitas Pgri Palembang. 3(2), 1-12.

Ismawati, D., \& Prasetyo, I. (2020). Efektivitas Pembelajaran Menggunakan Video Zoom 
Cloud Meeting pada Anak Usia Dini Era Pandemi Covid-19. Jurnal Obsesi : Jurnal Pendidikan Anak Usia Dini, 5(1), 665. https://doi.org/10.31004/obsesi.v5i1.671

Khasanah, S. U., \& Syarifah, A. (2021). Persepsi Mahasiswa Pendidikan Bahasa Inggris UIN Sunan Ampel Surabaya Terhadap Pembelajaran Daring Via Zoom Pada Masa Pandemi Covid-19. Edunesia: Jurnal Ilmiah Pendidikan, 2(1), 23-33. https://doi.org/10.51276/edu.v2i1.70

Maulana, H. A., \& Hamidi, M. (2020). Persepsi Mahasiswa terhadap Pembelajaran Daring pada Mata Kuliah Praktik di Pendidikan Vokasi. Equilibrium: Jurnal Pendidikan, 8(2), 224-231. https://doi.org/10.26618/EQUILIBRIUM.V8I2.3443

Monica, J., \& Fitriawati, D. (2020). Efektivitas Penggunaan Aplikasi Zoom Sebagai Media Pembelajaran Online Pada Mahasiswa Saat Pandemi Covid-19. Jurnal Communio: Jurnal Jurusan Ilmu Komunikasi, 9(2), 1630-1640. https://doi.org/10.35508/jikom.v9i2.2416

Mulyana, M., Rainanto, B. H., Astrini, D., \& Puspitasari, R. (2020). Persepsi Mahasiswa Atas Penggunaan Aplikasi Perkuliahan Daring Saat Wabah Covid-19. JAS-PT (Jurnal Analisis Sistem Pendidikan Tinggi Indonesia), 4(1), 47. https://doi.org/10.36339/jaspt.v4i1.301

Ningsih, S. (2020). Persepsi Mahasiswa Terhadap Pembelajaran Daring Pada Masa Pandemi Covid-19. JINOTEP (Jurnal Inovasi Dan Teknologi Pembelajaran): Kajian Dan Riset Dalam Teknologi Pembelajaran, 7(2), 124-132. https://doi.org/10.17977/UM031V7I22020P124

Prasani, A., Herdiyanti, D., Puspita, L., \& Walid, A. (2021). EVALUASI PEMBELAJARAN DARING TERHADAP MATERI PEMBELAJARAN IPA KELAS IX SMPN 18 KOTA BENGKULU. Academy of Education Journal, 12(2), 246-253. https://doi.org/10.47200/aoej.v12i2.437

Rusdiantho, K. S. G., \& Elon, Y. (2021). Persepsi Mahasiswa terhadap Pembelajaran Online Fase Pandemic Covid-19. Edukatif: Jurnal Ilmu Pendidikan, 3(5), 2573 2585. https://doi.org/10.31004/EDUKATIF.V3I5.899

Saha, S., Roy, H., \& Ray, K. (2021). Online anatomy lecture using zoom application and its learning experience of undergraduate medical students. 4.

Sakina, N., Nurmawati, S., Sarawati, Y., \& Walid, A. (2021). EVALUASI PEMBELAJARAN DARING TERHADAP MATA KULIAH STATISTIKA IPA IAIN BENGKULU. Academy of Education Journal, 12(1), 149-157. https://doi.org/10.47200/aoej.v12i1.436

Saragih, O., Sebayang, F. A. A., Sinaga, A. B., \& Ridlo, M. R. (2020). Persepsi Mahasiswa terhadap Pembelajaran Daring selama Pandemi Covid-19. Tarbiyah Wa Ta'lim: Jurnal Penelitian Pendidikan Dan Pembelajaran, 7(3), 178-191. https://doi.org/10.21093/TWT.V7I3.2624 